\title{
Workshop
}

\section{The Case for a National Strategic Plan for Consumer Horticulture Research, Education, and Extension}

\author{
Ellen M. Bauske ${ }^{1,8}$, Gary R. Bachman ${ }^{2}$, Tom Bewick ${ }^{3}$, \\ Lucy Bradley ${ }^{4}$, David Close ${ }^{5}$, Rick Durham ${ }^{6}$, \\ and Mary Hockenberry Meyer ${ }^{7}$
}

ADDITIONAL INDEX WORDs. gardening, funding, stakeholder

SumMary. Consumer horticulture encompasses interior and exterior ornamental, food, and community gardening. These activities influence the environment in many ways, affecting water quality and quantity, waste management, wildlife, and environmental sustainability. Consumer horticulture also impacts human health and well-being. In spite of keen consumer interest and the robust commercial impact, there is a paucity of support for consumer horticulture at both the state and federal levels. To explore strategies for increasing support for consumer horticulture, a workshop with four presentations was held at the annual conference of the American Society for Horticultural Science on 31 July 2014 in Orlando, FL. Presentations described the formation of a new Southern Experiment Extension/ Research Activity, Landscapes and Gardens for Better Living (SERA44); the local funding sources and local issues that focus research, education, and extension efforts in consumer horticulture; and the need to develop shared goals to drive regional projects. The need for a national strategic plan for consumer horticulture, and a process for creating one, was outlined. A strategic plan could galvanize the support of diverse stakeholders; focus research, education, and extension efforts; and build a strong case for resources dedicated to consumer horticulture.

$\longrightarrow$

onsumer horticulture embraces a broad range of activities of interest to the gardening public (Bauske et al., 2014). It encompasses interior and exterior ornamental gardening, food gardening, and community gardening. These activities affect the environment in many ways and are intimately intertwined with aesthetics, preference, and human well-being. They impact water, waste management, climate, and environmental sustainability (Carey et al., 2013; Zhou, 2014). The ecological services provided by gardens include conserving biodiversity, improving microclimate, and sequestering carbon (Lin et al., 2015; Lovell and Taylor, 2013; Wilde et al., 2015). Consumer horticulture also affects human health and wellbeing (Hall and Dickson, 2011).

Stakeholders include the gardening public, the green industry, environmental organizations, public health agencies, institutional organizations, and businesses. Even when narrowed to home and community food gardening, the gardening audience is immense. In 2008, 31\% of all U.S. households (an estimated 36 million households) participated in food gardening (National Gardening
Association, 2009) and the number increases annually (Butterfield, 2013). This broad cross section of the U.S. population includes all ages, education levels, income levels, marital statuses, household sizes, genders, and regional locations. Consumer horticulture stakeholders also include Extension Master Gardener (EMG) volunteers. There were $\approx 95,000$ active volunteers in the United States and Canada in 2009 (Cooperative State Research, Education and Extension Service, 2009). The stakeholder group logically expands to water purveyors, national chain stores, local stores, farmers markets, nurseries, and other businesses, which create and sell goods and services to the gardening public.

Despite public interest, commercial value, and the potential human health and environmental benefits of consumer horticulture, state and federal support are minimal. Few resources are dedicated to consumer horticulture research, education, and extension. Most consumer horticulture specialists have extension appointments with little or no responsibility for research or support from research teams.

In addition, the U.S. Department of Agriculture's (USDA) National Institute of Food and Agriculture (NIFA) grant options offer little support specifically directed toward home gardening activities. The USDA Strategic Plan for 2014-18 (USDA, n.d.) does not acknowledge urban gardening and this is reflected in NIFA's grant programs. Vegetable gardening is tangential to the USDA's focus on rural prosperity and agricultural production. Only the People's Garden Grant Program, a small program that funded nine projects for $\$ 614,500$ in 2011 (NIFA, n.d.), specifically targeted food, recreation, and/or wildlife gardens in urban and rural areas.

The Consumer Horticulture and Master Gardener (CHMG) Working Group of ASHS hosted a workshop with the goal of exploring these issues. Workshop presenters shared the work being done by the Southern Experiment Extension/Research Activity, Landscapes and Gardens for Better Living (SERA44) and examined opportunities for funding. The topics were chosen to encourage participants to join the process of creating a national strategic plan for consumer horticulture. They highlighted multistate programs in the North Central region and 
they discussed the creation of a strategic plan that would build support among the various stakeholders and focus national research, education, and extension efforts.

\section{Materials and methods}

The CHMG Working Group held a workshop on 31 July 2014 at the annual conference of ASHS in Orlando, FL (Bauske, 2014). Dr. Richard Durham of the University of Kentucky described the historical background, creation, and mission of the Southern Association of Agricultural Experiment Station Directors (SAAESD) SERA44 (Durham, 2014). Mr. David Close of Virginia Tech described the funding challenges and opportunities in consumer horticulture (Close, 2014). Dr. Mary Meyer of the University of Minnesota outlined the key components of successful multistate collaborative projects (Meyer, 2014). Dr. Gary Bachman of Mississippi State University presented a prerecorded interview by Dr. Lucy Bradley of North Carolina State University with Dr. Tom Bewick, National Program Leader of Plant Sciences of NIFA (Bachman, 2014). Dr. Bewick's interview outlined the benefits and process of developing a national strategic plan for consumer horticulture research, education, and extension. The four presentations are summarized here.

\section{Results and discussion}

Creation and Mission of SERA44. Several consumer horticulture specialists, EMG coordinators, and specialists in related disciplines attended an SAAESD grant-writing

\footnotetext{
This paper is in conjunction with a Workshop titled "The Science of Consumer Horticulture," which was held on Thursday, July 31, 2014, at the ASHS Annual Conference in Orlando, FL.

${ }^{1}$ Center for Urban Agriculture, University of Georgia, 1109 Experiment Street, Griffin, GA 30223

${ }^{2}$ Coastal Research and Extension Center, Mississippi State University, 1815 Popps Ferry Road, Biloxi, MS 39532

${ }^{3}$ USDA/National Institute of Food and Agriculture Institute of Food, Production and Sustainability, 1400 Independence Avenue SW, Mailstop 2220, Washington, DC 20250

${ }^{4}$ Department of Horticultural Science, 128 Kilgore Hall, Box 7609, North Carolina State University, Raleigh, NC 27695

${ }^{5}$ Department of Horticulture, Saunders 401-C, Virginia Tech, 490 West Campus Drive, Blacksburg VA 24061

${ }^{6}$ Department of Horticulture, N-318 Ag Science North, University of Kentucky, Lexington, KY 40546-0091

${ }^{7}$ Department of Horticultural Science, 1970 Folwell Avenue, University of Minnesota, St. Paul, MN 55108

${ }^{8}$ Corresponding author. E-mail: ebauske@uga.edu.
}

workshop in Atlanta, GA 27-28 Nov. 2012. The group's goal was to develop ideas and to formulate a successful consumer horticulture grant proposal. Food gardening was selected as a focus area for research, education, and extension.

It soon became clear that the group needed to expand its membership. Creating a successful grant proposal would require close collaboration with additional partners. Proposals addressing water quality, environmental impacts, and human health and well-being would need significant input from a more diverse group of specialists and scientists.

The team applied to the SAAESD to create a Southern Extension/ Research Activity (SERA). The application was accepted contingent on defining research objectives and SERA44 was created. Bimonthly virtual meetings, a listserv, shared web space, and a group newsletter (Landscapes and Gardens for Better Living Newsletter, n.d.) keep the group connected.

SERA44 is now a national working group. Participation in the group is not limited to the southern regions. Policies vary from university to university, but members of SERAs may request travel support for participation in SERA activities. Interested parties can join the group by contacting the experiment station director (or administrator who performs that function) at their institution. Additional information is available at the National Information Management and Support System (2001).

SERA44 participants considered several research projects and objectives, but struggled to find an effective regional approach to local issues most members focused their state programs on. Participants also failed to identify appropriate funding sources to support regional projects (see below). After considerable deliberation, the group decided to explore the possibility of creating a strategic plan that would give direction to future research, education, and extension efforts and identify shortfalls in funding for crucial efforts.

FUNDiNg CHALLENGES AND OPPORTUNITIES. SERA44 members continued holding conference calls to explore collaborative projects and seek funding. Specialty Crop Research Initiative, Agriculture and Food Research Initiative, Sustainable Agriculture Research and Education Grants, and the Organic Agriculture Research and
Extension Initiative were explored. These funding sources focus on agricultural production and rural populations. Group members had participated in NIFA-funded projects in integrated pest management (IPM), food, nutrition and health, and environmental and natural resources. Nevertheless, their participation tended to focus on public outreach, and rarely addressed consumer horticulture science issues. The Environmental Protection Agency and the National Institute of Health were also investigated as potential funders. It was clear that expertise outside of consumer horticulture was necessary to create successful proposals to these agencies. The group actively sought and recruited members in other fields to broaden its expertise.

In spite of the funding challenges, group members had successfully garnered support for outreach components for their individual programs. The funding sources tended to be dependent on local conditions and focused on in-state work. A few examples from the Virginia EMG program illustrate this. Examples presented at the workshop included: 1) the U.S. Department of the Interior, National Park Service funded the development of educational resources to discourage home debris burning and encourage composting; 2) funding from the EMG state association was used to create an endowment for the EMG coordinator position; and 3) the Virginia Department of Conservation \& Recreation provided funding for EMG volunteers to help home owners develop landscape nutrient management plans.

Multistate collaborative PROJECTS. Successful regional collaborative projects share several key elements including shared support for the goals and objectives and a firm commitment to listening and responding to feedback. If the project is a national effort, participants must think beyond their state. It is also important that participants' efforts in multistate collaborative projects be recognized in performance evaluations.

A STRATEGIC PLAN FOR CONSUMER HORTICULTURE. Consumer horticulture is underrepresented in federal grant portfolios, given the importance of its contributions to human health and environmental sustainability, the number of people who participate in gardening, and the diversity of industries that sell goods and 
services to the gardening public. By bringing stakeholders together, consumer horticulture may be able to gain greater visibility (and support) at the state and national level.

The development of a national strategic plan for research, education, and extension has effectively engaged stakeholders in other horticultural industries (Citrus Research Foundation, 2014; National Berry Crops Initiative, 2014; National Grape and Wine Initiative, 2007). Dr. Bewick suggested the same process could be used to engage consumer horticulture stakeholders, focusing attention and efforts on high impact, fundable areas. A national strategic plan can be easily adapted for local needs. It would be useful at the state and county level as well.

As noted previously, consumer horticulture stakeholders are a diverse group and include people involved in all aspects of gardening and the commercial, health, and ecological impacts associated with gardening. Ideally, the process of creating a strategic plan would galvanize this diverse and often fragmented stakeholder community, though it may be challenging to get participation and buy-in from all.

A small steering committee would be recruited to develop a draft national strategic plan. The steering committee should have representation from all sectors and be as inclusive as is practical. Once the draft plan is created, a series of conferences/listening sessions (both face-to-face and online) would be held to present the plan and obtain feedback from stakeholders. The plan would then be refined in a conference involving all of the participants. The ASHS annual meetings would play a crucial role in communicating developments throughout the process.

An organization must be created to manage the consumer horticulture strategic plan. Several other groups have done this successfully. The National Grape and Wine Initiative (2007), Citrus Research and Development Foundation (2014), and National Berry Crops Initiative (2014) are examples. The first two organizations have an elaborate structure with paid personnel and regular meetings; the third has a more informal structure with no paid staff and occasional meetings.

\section{Conclusions}

The CHMG Workshop held 31 July 2014 presented a call to action and provided a general roadmap for the creation of a strategic plan for research, education, and outreach in consumer horticulture. Participants in the workshop were enthusiastic about the value of creating a national strategic plan. Those interested in participating in the efforts were encouraged to join SERA44.

In 2014, the SERA44 group resubmitted its goals and objectives to accommodate the development of a strategic plan. SERA44 has provided an organizational structure for plan development and the group is pursuing this project. The small steering committee has been recruited and is developing a draft national strategic plan.

\section{Literature cited}

Bachman, G. 2014. Defining Research Goals: An Interview with Dr. Tom Bewick, National Program Leader, Horticulture USDA/NIFA. 8 Dec. 2014. <https://ashs.confex.com/ashs/2014/ webprogramarchives/Paper18869.html>.

Bauske, E.M. 2014. The science of consumer horticulture. HortScience 49:S109 (abstr.).

Bauske, E.M., G.R. Bachman, L.K. Bradley, K. Jeannette, A. Stoven O'Connor, and P.J. Bennett. 2014. Consumer horticulture outreach: Communication challenges and solutions. HortTechnology 24:266-269.

Butterfield, B. 2013. New 2013 national gardening survey. 15 Jan. 2014. <http:// www.garden.org/articles/articles.php? $\mathrm{q}=$ show\&id $=3737>$.

Carey, R.O., G.J. Hochmuth, C.J. Martinez, T.H. Boyer, M.D. Dukes, G.S. Toor, and J.L. Cisar. 2013. Evaluating nutrient impacts in urban watersheds: Challenges and research opportunities. Environ. Pollut. 173:138-149.

Citrus Research and Development Foundation. 2014. Citrus Research and Development Foundation, Inc. 3 Nov. 2014. <http://citrusrdf.org/>.

Close, D. 2014. Funding challenges and open discussion of options and opportunities. 8 Dec. 2014. <https://ashs.confex. com/ashs/2014/webprogramarchives/ Paper18909.html>.

Cooperative State Research, Education, and Extension Service. 2009. $2009 \mathrm{Ex}-$ tension Master Gardener Survey. 11 Nov. 2013. <https://www.extension.org/ mediawiki/files/f/f5/Extension_MG_ Survey_4-9.pdfs.

Durham, R.E. 2014. Getting Started: Landscapes and Gardens for Better Living Southern Region Research Activity and Open Discussion of Research Objective. 8 Dec. 2014. <https://ashs.confex.com/ ashs/2014/webprogramarchives / Paper18910.html>.

Hall, C.R. and M.W. Dickson. 2011. Economic, environmental, and health/ well-being benefits associated with green industry products and services: A review. J. Environ. Hort. 29:96-103.

Landscapes and Gardens for Better Living Newsletter. n.d. Email Campaign Archive. 15 Sept. 2014. <http://usl.campaignarchive $2 . c o m / h o m e / ? \mathrm{u}=1 \mathrm{c} 8272 \mathrm{lfbaa}$ $3 d 39936681$ b94d\&id=fffl f1 $7 d 28>$.

Lin, B.B., S.M. Philpott, and S. Jha. 2015. The future of urban agriculture and biodiversity-ecosystem services: Challenges and next steps. Basic Appl. Ecol. 16:189-201.

Lovell, S.T. and J.R. Taylor. 2013. Supplying urban ecosystem services through multifunctional green infrastructure in the United States. Landscape Ecol. 28:1447-1463.

Meyer, M. 2014. Working together \& building effective teams: North Central Consumer Hort IPM Working Group. HortScience 49:S109 (abstr.).

National Berry Crops Initiative. 2014. About NBCI. 3 Nov. 2014. <http:// nationalberrycrops.org/>.

National Gardening Association. 2009. The impact of home and community gardening in America. Scotts Miracle-Gro Co., Marysville, $\mathrm{OH}$.

National Grape and Wine Initiative. 2007. Welcome to the National Grape \& Wine Initiative. 3 Nov. 2014. <http://www. ngwi.org/>.

National Information Management Support System. 2001. NIMSS National Information Management and Support System. 17 Sept. $2014<$ http://nimss.umd.edu/>.

National Institute of Food and Agriculture. n.d. People's Garden Grant Program. 3 Sept. 2014. <http://www.usda. gov/wps/portal/usda/usdahome? contentidonly $=$ true\& contentid $=$ grant program_recipients.html>.

U.S. Department of Agriculture. n.d. Strategic Plan FY 2014-2018. 3 Sept. 2014. <http://www.ocfo.usda.gov/ usdasp/sp2014/usda-strategic-plan-fy2014-2018.pdf>.

Wilde, H.D., K.J.K. Gandhi, and G. Colson. 2015. State of the science and challenges of breeding landscape plants with ecological function. 21 May 2015. <http://www.nature.com/articles/ hortres201469>.

Zhou, Q. 2014. A review of sustainable urban drainages systems considering the climate change and urbanization impacts. Water 6:976-992. 